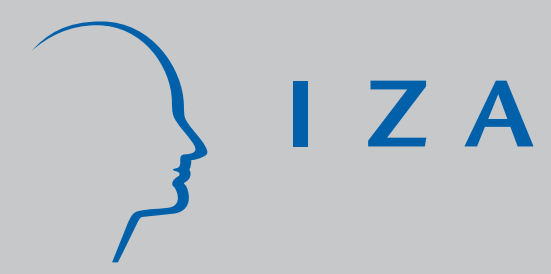

IZA DP No. 8374

The Role of Historical Resource Constraints in Modern Gender Inequality: A Cross-Country Analysis

Gautam Hazarika

Chandan Kumar Jha

Sudipta Sarangi

August 2014

Forschungsinstitut zur Zukunft der Arbeit Institute for the Study of Labor 


\title{
The Role of Historical Resource Constraints in Modern Gender Inequality: A Cross-Country Analysis
}

\author{
Gautam Hazarika \\ University of Texas at Brownsville \\ and IZA \\ Chandan Kumar Jha \\ Louisiana State University \\ Sudipta Sarangi \\ Louisiana State University \\ and National Science Foundation
}

Discussion Paper No. 8374

August 2014

IZA

P.O. Box 7240

53072 Bonn

Germany

Phone: +49-228-3894-0

Fax: +49-228-3894-180

E-mail: iza@iza.org

Any opinions expressed here are those of the author(s) and not those of IZA. Research published in this series may include views on policy, but the institute itself takes no institutional policy positions. The IZA research network is committed to the IZA Guiding Principles of Research Integrity.

The Institute for the Study of Labor (IZA) in Bonn is a local and virtual international research center and a place of communication between science, politics and business. IZA is an independent nonprofit organization supported by Deutsche Post Foundation. The center is associated with the University of Bonn and offers a stimulating research environment through its international network, workshops and conferences, data service, project support, research visits and doctoral program. IZA engages in (i) original and internationally competitive research in all fields of labor economics, (ii) development of policy concepts, and (iii) dissemination of research results and concepts to the interested public.

IZA Discussion Papers often represent preliminary work and are circulated to encourage discussion. Citation of such a paper should account for its provisional character. A revised version may be available directly from the author. 
IZA Discussion Paper No. 8374

August 2014

\section{ABSTRACT}

\section{The Role of Historical Resource Constraints in Modern Gender Inequality: A Cross-Country Analysis}

We posit that historical resource scarcities played a role in the emergence of gender norms inimical to women that persist to this day. This thesis is supported by our finding that nations' historical resource endowments, as measured by the historical availability of arable land, are statistically significantly negatively related to their present levels of gender inequality, as gauged by the United Nations Development Programme's Gender Inequality Index.

JEL Classification: N90, O15

Keywords: gender, history, culture, scarcity

Corresponding author:

Gautam Hazarika

Department of Finance and Economics

The University of Texas at Brownsville

One University Blvd.

Brownsville, TX 78520

USA

E-mail: gautam.hazarika@utb.edu

\footnotetext{
* Any opinion, findings, and conclusions or recommendations expressed in this material are those of the authors and do not necessarily reflect the views of the National Science Foundation.
} 


\section{Introduction}

This paper investigates the effect of nations' historical resource constraints upon their current levels of gender inequality, and, so, pursues a line of inquiry into the historical roots of culture. Three arguments serve as its rationale. First, there is a connection between resource constrainedness and gender discrimination at the level of the household, in that household poverty has been observed to exacerbate intra-household gender inequities. Second, a relationship between resource constrainedness and discrimination is discernible even at the societal level. Third, culture can be persistent, so that it is possible influences upon culture in the past continue to hold sway.

A number of studies of intra-household gender discrimination in less developed countries, and all countries were less developed once, find that this is more pronounced in poorer households. For example, De'Tray (1988) ascertains that Malaysian households' demand for the schooling of girls is more income-elastic than their demand for boys' schooling, Behrman (1988) learns that rural Indian households' favoring of boys in the allocation of nutrition is greatest during the lean agricultural season, and Alderman and Gertler (1997) discover that Pakistani households' demand for the health care of unwell children is more income-elastic in the instance of ill girls. Alderman and Gertler find that demand for the health care of ill girls is more priceelastic as well, though this gender difference diminishes in household income, suggesting that a tightening of resource constraints, by a price rise in this instance, will exacerbate intra-household gender bias, especially in needier households. In sum, there is sufficient evidence of a relation between resource constrainedness and gender discrimination at the level of the household. Research (e.g., Hazarika, 2000) suggests that the root of this parental favoring of sons is their greater investment value, which stems in part from the common custom of patrilocal residence.

Some perceive a connection between resource constrainedness and discrimination even at the societal level. Bigotry thrives in ailing economies, holds Brackman (2008). He contends, for instance, that past economic slumps in the United States, from the recession set off by the Panic of 1837 to the Great Depression, saw surges in anti-Semitic, anti-Catholic, and anti-immigrant sentiment. A number of economic 
studies uncover evidence in keeping with this contention. For example, Schmitz and Gabriel (1992) find that divergence between the occupational distributions of black and white males in the U.S., and between the occupational distributions of white females and white males, is greater in more economically depressed metropolitan areas, that is, deteriorating local economic conditions cause black males and white females to suffer greater occupational segregation. Similarly, McLennan (2003) determines that the employment prospects of American black men are more sensitive to local economic conditions than these prospects of white men, with the result that black men suffer greater increases in unemployment in local economic downturns. A recent series of psychological experiments too yield evidence of intensified bigotry in times of scarcity. Krosch and Amodio (2014) discover that economic scarcity alters perceptions of race. When primed with scarcity, their mostly Caucasian study subjects were likelier to perceive mixed-race faces as Black, and Black faces as darker and more stereotypically Black, and this change in perception caused the study subjects to become less generous towards the darker complexioned. In sum, just as the economic circumstances of households shape intra-household gender discrimination, the economic circumstances of whole societies may shape their discriminatory norms.

Might societal resource scarcity in the past act upon gender inequality at present? It might, maintains this paper, since culture can be persistent. There is mounting evidence of the deep economic-historical roots of culture. For example, Nunn and Wantchekon (2011) find that Africans today whose ethnic groups most acutely suffered kidnapping and transportation during the Slave Trade are more mistrustful of their relatives, neighbors, coethnics, and local governments, Duleep (2012) discovers that the Indian caste system, within which upper castes often coerce labor from the lower castes, is more orthodox and rigid in regions with historically lower endowments of labor relative to land, and Alesina, Giuliano, and Nunn (2013) determine that gender norms are more unequal in societies in which plough agriculture is traditional, being less unequal in societies in which the hoe has been the implement of choice. This persistence of culture permits a society's past resource endowment to remain a significant cultural influence.

Indeed, this study finds that nations' historical resource endowments, as measured by the historical availability of arable land, are significantly negatively related to their present levels of gender inequality, as 
gauged by the United Nations Development Programme’s (UNDP) Gender Inequality Index. This negative relationship is robust to the inclusion of a variety of geographical, contemporary, and historical controls.

The remainder of this paper is organized as follows. Section 2 describes the empirical strategy, as well as the utilized data. Section 3 presents the study's findings. Section 4 offers certain supportive stylized facts, discusses a plausible indirect connection, involving farmers' adoption of the plough, between the supply of arable land and gender inequality, as well as summarizes our findings.

\section{Empirical Model and Data}

Our empirical model consists of cross-country regression equations, in each of which the dependent variable measures national gender inequality and the principal independent variable gauges nations' historical resource constrainedness.

National gender inequality is measured by the UNDP's Gender Inequality Index for the year 2012. The Gender Inequality Index summarizes women's disadvantages in the areas of reproductive health, empowerment, and the labor market ${ }^{1}$. Their hardships in the area of reproductive health are described by the Maternal Mortality Ratio (MMR), equivalent to the number of maternal deaths per 100,000 live births, and the Adolescent Fertility Rate (AFR), computed as the number of births per 1000 fifteen to nineteen year old women. Women's and men's shares of seats in parliament, and the proportions of adult women and men with secondary or higher education, gauge the levels of empowerment of the genders, and women's and men's labor force participation rates measure the genders' standing in the labor market. The Gender Inequality Index increases in gender inequality, ranging, in 2012, from 0.045 (Netherlands) to 0.747 (Yemen). Figure 1 presents a world choropleth map of gender inequality per the UNDP's Gender Inequality Index. It indicates that gender inequality is concentrated in the Middle East, South Asia, and North-East, Central, and West Africa.

Nations' historical resource constrainedness is measured in three alternative ways. Our first measure consists of the shares of nations' lands that are potentially arable, that is, suited to rainfed cultivation. The

\footnotetext{
${ }^{1}$ The UNDP's methodology is described in http://hdr.undp.org/sites/default/files/hdr_2013_en_technotes.pdf.
} 
Food and Agricultural Organization of the United Nations (FAO) has estimated each country's potential arable land (FAO, 2000). In most cases, potential arable land exceeds actual arable land, in that a portion of potential arable land, such as currently forested land, hasn't yet been brought under cultivation. In a few countries, however, such as Egypt, modern irrigation has permitted actual arable land to exceed land suited to rainfed cultivation. The FAO bases its estimates of potential arable land on a soil map of the world that identifies major soil constraints such as salinity, a global climatic database, and a database on the climatic and soil requirements of 21 major crops. For the following reasons, it is reasonable to accord historical import to the FAO's estimates of current potential arable land. First, agriculture has become the mainstay of mankind since the Neolithic Revolution 12,000 years ago, and potential arable land speaks to the agricultural potential of a region in the absence of modern irrigation and technologies that mitigate soil constraints. Second, a modern soil map of the world is also historical, as are the climatic and soil requirements of mankind's main crops, in that almost nothing has changed in their regard. Third, while the world's climate has seen considerable change during the geological epoch of the Holocene ${ }^{2}$, within which the Neolithic Revolution occurred, it has, at any rate, been fairly stable for the past one to two millennia. For example, Jones and Mann (2004) write:

"When we restrict our attention to the more limited interval of the past one to two millennia, a period that can be referred to as the 'late Holocene' ... the principal boundary conditions on the climate (e.g., Earth orbital geometry and global ice mass) have not changed appreciably. The variations in climate observed over this time frame are likely therefore to be representative of the natural climate variability that might be expected over the present century in the absence of any human influence."

Consequently, the percentage of a nation's land that is potentially arable, is an appealing measure of its historical resource endowment.

${ }^{2}$ For example, there is evidence of ancient lakes in what is now the Sahara desert. 
Our second measure of nations' historical resource endowments is per capita potential arable land in the year 1 AD. It may be a fitter measure of historical resource constrainedness than the shares of nations' lands suited to rainfed cultivation since it explicitly accounts for the number of mouths that needed to be fed. We base our choice of the year $1 \mathrm{AD}$ upon the assessment that the historical applicability of the FAO's estimates of potential arable land only extends to the past one to two millennia, since the world's climate may have been considerably different before then (Jones and Mann, 2004). Our measure is arrived at by dividing the FAO's estimates of nations' lands suited to rainfed cultivation by McEvedy's and Jones's (1978) estimates of these nations' populations in the year $1 \mathrm{AD}$. McEvedy and Jones supply estimates of the historical populations of regions corresponding to nation states as these stood in the year 1975, or to sets of two or three neighboring nation states in some instances. When these data referred to a set of neighboring countries, a common population density was calculated for the set as a whole. This was multiplied by the land area of each member of the set to arrive at its individual historical population. A convenient secondary source of these historical population data is the data appendix ${ }^{3}$ to a study by Ashraf and Galor (2013).

We obtain our third measure of nations' historical resource constrainedness from a study by Alesina, Giuliano, and Nunn (2013). This measure pertains to ancestral rather than mere historical resource constrainedness. Alesina, Giuliano, and Nunn aptly recognize that nations are commonly made up of a number of ethnic groups. Each ethnic group has a historical centroid, a place whence they originated. Alesina, Giuliano, and Nunn acquire the geographical coordinates of these ethnic centroids from a colossal piece of ethnographic scholarship by the late American anthropologist George Peter Murdock called the Ethnographic Atlas ${ }^{4}$. They then use GIS software to identify land within 200 kilometers of each such centroid. This land may be termed the concerned ethnic group's ancestral land. Alesina, Giuliano, and Nunn subsequently use an FAO database to calculate the share of each ethnic group's ancestral land suited to agriculture, that is, to the cultivation of six major crops. Finally, they compute the share of a nation's ancestral lands suited to agriculture as the weighted mean of the shares of its constituent ethnic groups' ancestral lands suited to

\footnotetext{
${ }^{3}$ accessible at http://www.aeaweb.org/articles.php?doi=10.1257/aer.103.1.1

${ }^{4}$ Electronic versions of Murdock's Ethnographic Atlas may be downloaded at the links 'Ethnographic Atlas coded data in Excel' or 'Ethnographic Atlas coded data in SPSS' in http://eclectic.ss.uci.edu/ drwhite/worldcul/SCCSarticles.htm.
} 
agriculture, the weights being the shares of these groups' numbers in the national population. Converted to percentages, these shares of nations' ancestral lands suited to agriculture make up our third measure of national historical resource constrainedness ${ }^{5}$.

We estimate the following three linear regression equations:

Gender Inequality Index ${ }_{i}=a_{1}+a_{2}(\log$ percentage of land that is potentially arable $i)+\boldsymbol{X}_{1, i}{ }^{\prime} \mathbf{a}_{3}$,

Gender Inequality Index $i=b_{1}+b_{2}\left(\log\right.$ potential arable land per capita in $\left.1 A D_{i}\right)+\boldsymbol{X}_{\mathbf{1 , i}}{ }^{\prime} \boldsymbol{b}_{\mathbf{3}}$,

and

Gender Inequality Index $i=c_{1}+c_{2}(\log$ percentage of ancestral land suited to agriculture $i)+\boldsymbol{X}_{2, i}{ }^{\prime} c_{3}$,

wherein the subscript $i$ alludes to country $i$, the regressors $\boldsymbol{X}_{1, i}$ include contemporary and geographical controls, and the regressors $\boldsymbol{X}_{2, i}$ include contemporary controls, as well as geographical and historical controls pertaining to the ancestral lands of country $i$ s constituent ethnic groups in the manner of our third measure of national historical resource constrainedness. Since the explanatory variables likely exert diminishing marginal effects upon gender inequality, we elect to take the natural logs of all explanatory variables amenable to $\log$ transformation, that is, with exclusively positive values.

Since there were no people of European descent in the Americas or Oceania in the year 1 AD, potential arable land per capita in $1 \mathrm{AD}$ in these regions pertains only to native peoples. It is unlikely modern gender inequality in these areas is significantly influenced by the cultures of their native peoples, except perhaps in countries in which native populations predominate. Therefore, equation (2) is estimated upon a sub-sample of nations that excludes those in the New World in which Europeans make up half or more of the population. Furthermore, each equation must be estimated upon a sub-sample of nations for which data in regard to its dependent and independent variables are obtainable.

\section{Results}

Table 1 presents estimates pertaining to two versions of equation (1), a pared-down or baseline version and a more elaborate extended version. Nations' endowments of potential arable land measure their

\footnotetext{
${ }_{5}$ These data may be found in http://scholar.harvard.edu/files/nunn/files/plough_replication_files.zip.
} 
historical resource constrainedness. The other explanatory variables, shared by equation (2), are conceivably either direct influences upon culture, or, since culture may have an economic basis, indirect influences by way of their role in economic development.

Geography has long been considered an important factor in economic development (e.g., Gallup, Sachs, and Mellinger, 1999). Rainfall and temperature have direct bearing upon agricultural productivity, as do elevation and terrain roughness. Terrain roughness can be an impediment to overland trade as well, with untoward consequences for economic development. However, it may also be a blessing, by obstructing foreign malevolent forces. For example, Nunn and Puga (2012) argue that the ruggedness of the terrain in parts of Africa proved to be a boon in that it thwarted slave traders. African countries with rugged geographies were, thus, protected from the disruptive effects of the Slave Trade, and this benefit is reflected in their economic development. The fraction of land in the tropics is included as a regressor since, as Gallup, Sachs, and Mellinger (1999) put it, "tropical regions are hindered in development relative to temperate regions, probably because of higher disease burdens and limitations on agricultural productivity." Distance from the coast or sea-navigable river is included since it is a factor in transportation costs, hence economically beneficial trade. The fraction of land in which malaria is endemic is controlled for since the economic burden of this disease is very substantial (e.g., Sachs and Malaney, 2002).

Since we aim to estimate the effect of historical resources constrainedness upon modern gender inequality, it is imperative that we control for contemporary circumstances. Thus, we control for contemporary per capita income, the shares of agriculture and industry in GDP, and the religious composition of the populace. Religion often shapes culture directly, but its influence may be indirect as well, since, as many have argued, religion plays a role in culture-shaping economic development. For example, Weber (1930) famously wrote of a 'Protestant Ethic' conducive to prosperity, and Kuran (2011) holds that the inheritance rules of Islam may have held back economic development by hindering the accumulation of wealth, the longevity of commercial partnerships, and the establishment of large-scale enterprises. Since war is certainly deleterious to economies, we control for the number of civil and inter-state conflicts in the past two centuries. Since communists have invariably been preoccupied with issues of women's equality, we mark 
nations with experience of communism. We also control for European heritage, both in order to factor in European cultural norms and to account for its role in economic development in light of Spolaore's and Wacziarg's (2009) contention that genealogical distance between peoples facilitates the diffusion of advantageous technological and institutional innovations. We include continent dummy variables, with Northern Africa as the omitted category, to account for unobserved broad regional influences.

By the estimates of the coefficients of equation (1), gender inequality appears positively related to temperature and negatively related to terrain roughness. It decreases in contemporary per capita income once a certain low income threshold is crossed, and decreases in agriculture's share of GDP. Ceteris paribus, gender inequality is greater in North and South America and Sub-Saharan Africa than in Northern Africa, and greater as well in countries more deeply penetrated by Islam.

Notably, by the estimates of the coefficients of both the baseline and extended versions of equation (1), increase in the proportion of potential arable land is statistically significantly associated with decrease in gender inequality: a one percent increase in the share of a country's land area that is potentially arable, reduces its expected value of the Gender Inequality Index by approximately 0.0002 .

Table 2 presents estimates of the coefficients of equation (2). By the estimates pertaining to the equation's baseline version, gender inequality statistically significantly increases in temperature. By the estimates of the coefficients of the equation's baseline and extended versions, gender inequality decreases in terrain roughness, and, once a certain low income threshold is crossed, in national per capita income. Ceteris paribus, gender inequality is greater in North and South America, Oceania, and Sub-Saharan Africa than in Northern Africa, and greater as well in countries in which Islam holds greater sway.

Importantly, by the estimates of the coefficients of both versions of equation (2), modern gender inequality is statistically significantly negatively related to the historical per capita availability of potential arable land. The estimates pertaining to the equation's baseline version indicate that a one percent increase in potential arable land per capita in the year $1 \mathrm{AD}$, lowers the expected value of the Gender Inequality Index by approximately 0.0002 . The corresponding figure in regard to the extended version of the equation is approximately 0.0001 . 
Table 3 presents estimates of the coefficients of equation (3). As discussed, this equation employs a measure of ancestral rather than mere historical resource constrainedness, as well as geographical and historical descriptors of the ancestral lands of nations' constituent ethnic groups, located within 200 kilometers of these groups' historical centroids. It is conceivable that these geographical and historical factors shaped ancestral cultures, either directly, or indirectly by way of their effects on ancestral economic conditions, and that these ancestral cultures have persisted to this day. Some of these geographical controls, such as temperature and rainfall, would match those included in equations (1) and (2) but for the fact that they pertain to lands whence the ancestors of nations' component ethnic groups originated. A noteworthy ancestral geographical variable is the fraction of ancestral lands suited to plough-benefited crops. Its inclusion is motivated by Alesina's, Giuliano's, and Nunn's (2013) discovery that traditional agricultural practices, the use of the plough in particular, continue to shape cultural norms governing the role of women in society. The extended version of equation (3) is considerably more elaborate than the extended versions of (1) and (2) in that its explanatory variables include a host of ancestral historical, or ethnographic, controls, all possible influences upon ancestral, and their descendent modern, cultures.

According to the estimates pertaining to the baseline version of equation (3), gender inequality is statistically significantly positively related to the average temperature in ancestral lands, and negatively related to the proportion of ancestral lands without significant soil depth constraints. In other words, there is more gender inequality in countries whose populations trace their ancestry to the hotter parts of the world, and less gender inequality in countries whose peoples originated in regions with superior soil. It is noteworthy in this context that tropical agriculture is $30 \%$ to $50 \%$ less productive than temperate zone agriculture (Gallup, Sachs, and Mellinger, 1999), and that thin soils are low in organic matter and moisture supplying capacity, hence fertility. The estimates in regard to both the baseline and extended versions of equation (3) indicate that gender inequality decreases in the terrain slope of ancestral lands. Gender inequality seems significantly greater in countries whose populations trace their ancestry to lands better suited to cultivation by the means of the plough. This is in keeping with Alesina's, Giuliano's, and Nunn's (2013) finding that the present gender norms of the descendents of peoples who traditionally employed the plough are more biased against women 
than the gender norms of the descendents of those who depended on the hoe. As before, gender inequality decreases in current per capita income once a certain low income threshold is crossed. Gender inequality is also statistically significantly negatively related to the share of agriculture in GDP. The estimates pertaining to the baseline version of equation (3) indicate that there is more gender inequality in Asia than in Northern Africa, ceteris paribus, whereas the estimates in regard to the equation's extended version point to more gender inequality in Oceania. Both sets of estimates indicate that there is greater gender inequality in North and South America and Sub-Saharan Africa than in Northern Africa, all else being equal. Once again, Islam appears associated with greater gender inequality.

It is especially noteworthy that gender inequality is statistically significantly negatively related to the agricultural suitability of ancestral lands. Estimates of the coefficients of both the baseline and extended versions of equation (3) indicate that a one percent increase in the share of ancestral lands suited to agriculture lowers the expected value of the Gender Inequality Index by approximately 0.0002 .

In sum, all three of our modes of cross-country inquiry point to a statistically significant negative relationship between modern gender inequality and historical access to cultivable land. This is supportive of our thesis that past economic scarcity, dictated by the lack of agriculturally suitable land, had a hand in the shaping of biased gender norms that persists to this day.

\section{Conclusion}

Besides summarizing our findings, this section offers certain stylized facts that, we hope, bolster our conclusion that historical resource constraints are a factor in modern gender inequality. Figure 2 presents a scatter plot of per capita income against the Gender Inequality Index. This scatter diagram has sizeable lateral spread. In other words, there is a considerable range of gender inequality among countries with comparable per capita incomes. Contrast, for example, Qatar to Switzerland, the United Arab Emirates to France, Saudi Arabia to Slovenia, and Afghanistan to Macedonia. Might differences in historical access to arable land explain some of the difference in gender inequality between, say, Saudi Arabia and Slovenia? By figure 3, Switzerland, France, Slovenia, and Macedonia are considerably better endowed with potential arable land 
than, respectively, Qatar, the United Arab Emirates, Saudi Arabia, and Afghanistan. Some may question these particular comparisons for the reason that Islam, which, arguably, enshrines a degree of gender inequality, is the dominant religion in all four of the above countries in which women are more disadvantaged. In other words, that these are apples-to-oranges comparisons may be an objection. However, religions arose in social contexts. Therefore, it is wholly plausible that they embraced aspects of the cultures within which they were born. After all, Christianity began to "absorb and Christianize pagan religious ideas and practices" in the fourth century (Bradshaw, 2002). Thus, Islam's view of women may really predate Islam, and it is not inconceivable that this view was shaped in part by the resource-poor environment of the Arabian Peninsula.

Figure 3 is suggestive of a negative relation between gender inequality and the endowment of arable land, in that the portrayed vertical spikes appear taller near the $\mathrm{Y}$-axis than further along the $\mathrm{X}$-axis, that is, countries more poorly endowed with potential arable land seem to suffer greater gender inequality. This negative relationship is perhaps more clearly viewed in figure 4, a rearrangement of figure 3 . The spikes portrayed in figure 4 seem taller nearer the $y$-axis than further along the x-axis, that is, countries in which there is less gender inequality appear better endowed with potential arable land.

The final stylized facts supportive of our thesis are found in table 4, which lists the country with the least gender inequality and that with the most gender inequality within each decile of per capita income. In the majority of deciles, the country with the least gender inequality has a larger percentage of potential arable land than the country with the most gender inequality. The $4^{\text {th }}$ and $8^{\text {th }}$ deciles are exceptions, in that Mongolia, with a much smaller proportion of potential arable land than the Republic of the Congo, nevertheless suffers less gender inequality, and Slovenia sees less gender inequality than Uruguay despite possessing a smaller percentage of potential arable land. Perhaps Slovenia, carved from former communist Yugoslavia, benefits from communism's preoccupation with gender equality. Mongolia too was communist once, but its advantage may lie as well in the nomadic pastoral character of its people. Diamond (1987) writes that "freed from the need to transport their babies during a nomadic existence, and under pressure to produce more

\footnotetext{
${ }^{6}$ Some 30 percent of its population remains nomadic or semi-nomadic.
} 
hands to till the fields, farming women tended to have more frequent pregnancies ${ }^{7}$. He also holds that "women in agricultural societies were sometimes made beasts of burden". So it is possible women in Mongolia suffer less gender inequality because theirs was never a life of settled agriculture.

Towards a last bolstering of our thesis of a connection between the historical availability of arable land and modern gender inequality, we offer the prospect of an indirect relationship between the two, based not on scarcity engendering the favoring of males but on the role of the scarcity of arable land in farmers' adoption of the plough. Alesina, Giuliano, and Nunn (2013) argue that the adoption of the plough diminished women's role in agriculture and led to a gender-based division of labor wherein women made their contributions from home. This division of labor, they contend, led to cultural norms biased against women. The advent of the plough was inimical to women's place in economic life for three reasons. First, the use of the plough calls for more upper body strength than women typically possess, both because it is a heavy implement and since the large draft animals that draw it must be controlled. Second, since small children in the vicinity of its operation are endangered by it, and ploughing isn't an activity conducive to frequent and unanticipated interruption, the plough may not be handled by persons whose other responsibility is childcare. Third, since the plough can cut the roots of weeds, its use may obviate the need for weeding, a task that mostly fell to women and children. While Alesina's, Giuliano's, and Nunn's is a persuasive argument, we, like Boserup (1965), hold that it is the availability of arable land that is at least partially instrumental in the adoption of the plough. Boserup (1965) argued that the plough becomes especially useful when the fallow period between crops is so short that fallow land is taken over by mere grass rather more substantial vegetation like bushes and trees. Slashing and burning easily clear bushes and trees, but the roots of grass are so resilient to fire that their removal is greatly helped by the plough. The duration of the fallow period, in turn, depends on the availability of arable land. Where arable land is scarce, farmers can ill afford to keep land fallow for long. Therefore, the adoption of the plough may be tied to the scarcity of arable land. Table 5 presents the results of an OLS regression of the proportions of nations' populations traced to ancestors who

\footnotetext{
${ }^{7}$ Recall that the Gender Inequality Index incorporates the Maternal Mortality Ratio and the Adolescent Fertility Rate. More frequent pregnancies tend to raise the Maternal Mortality Ratio, and the pressure to produce more hands to till the
} 
used the plough, against the proportions of nations' ancestral lands suited to agriculture, the proportions of nations' ancestral lands conducive to the cultivation of plough-benefited crops, and a host of other ancestral geographical and historical controls. The estimates point to a negative relation between ancestral plough use and the ancestral availability of agriculturally suitable land. In other words, it seems that the historical availability of arable land was a factor in the adoption of the plough, a change in agricultural technique that, by Alesina, Giuliano, and Nunn (2013), then altered societal norms in a manner that widened gender inequality.

In sum, this study seeks to discover whether historical resource constrainedness, gauged by the historical availability of arable land, is an influence upon modern gender inequality. It finds that the proportion of national land area that is potentially arable, potential arable land per capita in the year $1 \mathrm{AD}$, and the proportion of national ancestral land suited to agriculture are each statistically significantly negatively related to the UNDP's Gender Inequality Index. We consider this finding supportive our thesis that historical resource constrainedness played a role in the emergence of gender norms biased against women that remain to this day.

fields may well bring large numbers of adolescent girls into matrimony and child bearing. It is notable that the Total Fertility Rate in Mongolia is 2.4 as opposed to 5 in the Republic of the Congo. 
Table 1: Gender Inequality and Potential arable land

\begin{tabular}{|c|c|c|c|c|c|c|}
\hline \multirow{4}{*}{\begin{tabular}{|l|} 
\\
Dependent Variable \\
Gender Inequality Index in 2012 \\
\end{tabular}} & \multicolumn{2}{|c|}{ Sample Statistics } & \multicolumn{4}{|c|}{ OLS Estimates of Equation (1) } \\
\hline & \multirow{2}{*}{ Mean } & \multirow[t]{2}{*}{ S.E. } & \multirow{2}{*}{\multicolumn{2}{|c|}{\begin{tabular}{l|l} 
Coeff. & S.E. \\
\multicolumn{2}{c}{ baseline }
\end{tabular}}} & \multirow{2}{*}{\multicolumn{2}{|c|}{\begin{tabular}{|r|r|} 
Coeff. & S.E. \\
extended
\end{tabular}}} \\
\hline & & & & & & \\
\hline & 0.385 & 0.188 & & & & \\
\hline \multicolumn{7}{|l|}{ Explanatory Variables } \\
\hline constant & & & 0.1290 & 0.2797 & 0.0216 & 0.2954 \\
\hline \multicolumn{7}{|l|}{ Key Variable } \\
\hline $\begin{array}{l}\ln (\text { percentage of country's land area that is } \\
\text { potentially arable) }\end{array}$ & 3.106 & 2.072 & $-0.0247^{* * *}$ & 0.0057 & $-0.0234^{* * *}$ & 0.0058 \\
\hline \multicolumn{7}{|l|}{ Geo-Climatic Controls } \\
\hline $\ln$ (average yearly precipitation in $\mathrm{mm}$ ) & 6.688 & 0.898 & 0.0154 & 0.0162 & 0.0259 & 0.0173 \\
\hline monthly average temperature in degrees Celsius & 17.715 & 8.512 & $0.0082^{* * *}$ & 0.0021 & $0.0062^{* *}$ & 0.0024 \\
\hline $\ln ($ mean elevation in $\mathrm{km})$ & -0.928 & 0.913 & 0.0155 & 0.0198 & 0.0153 & 0.0208 \\
\hline $\ln$ (measure of terrain roughness) & -1.997 & 0.889 & $-0.0322^{*}$ & 0.0188 & $-0.0348^{*}$ & 0.0190 \\
\hline fraction of land area in the geographical tropics & 0.458 & 0.476 & -0.0803 & 0.0379 & -0.0653 & 0.0408 \\
\hline $\begin{array}{l}\ln \text { (mean distance in } \mathrm{km} \text { to nearest coastline or } \\
\text { sea-navigable river) }\end{array}$ & 5.045 & 1.279 & 0.0103 & 0.0113 & 0.0134 & 0.0129 \\
\hline fraction of land area in which malaria is endemic & 0.627 & 0.416 & 0.0195 & 0.0238 & $0.0403^{*}$ & 0.0240 \\
\hline \multicolumn{7}{|l|}{\begin{tabular}{|l|l} 
Contemporary Controls &
\end{tabular}} \\
\hline In(nominal per capita income in 2012 - USD) & 8.597 & 1.541 & 0.0543 & 0.0500 & $0.1083^{*}$ & 0.0591 \\
\hline $\begin{array}{l}\text { In(nominal per capita income in } 2012 \text { - USD) } \\
\text { squared }\end{array}$ & 76.063 & 26.890 & $-0.0071^{* *}$ & 0.0028 & $-0.0112^{* * *}$ & 0.0036 \\
\hline dummy variable for Asia & 0.286 & 0.453 & 0.0503 & 0.0443 & 0.0500 & 0.0456 \\
\hline dummy variable for Europe & 0.233 & 0.424 & 0.0278 & 0.0518 & 0.0643 & 0.0670 \\
\hline dummy variable for N. America & 0.105 & 0.308 & $0.1435^{* * *}$ & 0.0524 & $0.1443^{* *}$ & 0.0599 \\
\hline dummy variable for Oceania & 0.023 & 0.149 & 0.0730 & 0.0644 & 0.1110 & 0.0710 \\
\hline dummy variable for S. America & 0.090 & 0.288 & $0.1252^{* *}$ & 0.0532 & $0.1425^{* *}$ & 0.0601 \\
\hline dummy variable for Sub-Saharan Africa & 0.233 & 0.424 & $0.1301^{* *}$ & 0.0501 & $0.1193^{* *}$ & 0.0536 \\
\hline \multicolumn{7}{|l|}{ Additional Contemporary Controls } \\
\hline years of civil conflict $1816-2007$ & 8.571 & 15.298 & & & 0.0005 & 0.0006 \\
\hline years of inter-state conflict $1816-2007$ & 5.195 & 8.800 & & & 0.0002 & 0.0011 \\
\hline indicator of experience of communism & 0.271 & 0.446 & & & -0.0029 & 0.0216 \\
\hline fraction of population of European descent & 0.3479 & 0.4244 & & & -0.0377 & 0.0527 \\
\hline $\ln$ (agriculture's percentage share in GDP) & 1.941 & 1.245 & & & $-0.0336^{*}$ & 0.0174 \\
\hline In(industry's percentage share in GDP) & 3.359 & 0.404 & & & -0.0307 & 0.0246 \\
\hline fraction of population that is Catholic & 0.295 & 0.336 & & & 0.0275 & 0.0392 \\
\hline fraction of population that is Protestant & 0.113 & 0.176 & & & 0.0840 & 0.0560 \\
\hline $\begin{array}{l}\text { fraction of population belonging to other } \\
\text { Christian denominations }\end{array}$ & 0.090 & 0.122 & & & 0.0741 & 0.0809 \\
\hline fraction of population that is Muslim & 0.231 & 0.345 & & & $0.0964^{* *}$ & 0.0389 \\
\hline fraction of population that is Hindu & 0.024 & 0.102 & & & 0.0739 & 0.0780 \\
\hline Adjusted $\mathrm{R}^{2}$ & & & \multicolumn{2}{|c|}{0.8398} & \multicolumn{2}{|c|}{0.8507} \\
\hline $\mathrm{n}$ & \multicolumn{6}{|c|}{133} \\
\hline
\end{tabular}

Note: The superscripts ${ }^{* * *},{ }^{* *}$, and ${ }^{*}$ denote significance at the $1 \%, 5 \%$, and $10 \%$ levels, respectively. 
Table 2: Gender Inequality and Potential Arable Land Per Capita in the Year $1 \mathrm{AD}$

\begin{tabular}{|c|c|c|c|c|c|c|}
\hline & \multicolumn{2}{|c|}{ Sample Statistics } & \multicolumn{4}{|c|}{ OLS Estimates of Equation (2) } \\
\hline & Mean & S.E. & Coeff. & S.E. & Coeff. & S.E. \\
\hline Dependent Variable & & & \multicolumn{2}{|c|}{ baseline } & \multicolumn{2}{|c|}{ extended } \\
\hline Gender Inequality Index in 2012 & 0.385 & 0.198 & & & & \\
\hline \multicolumn{7}{|l|}{ Explanatory Variables } \\
\hline constant & & & 0.1039 & 0.3835 & -0.1281 & 0.4564 \\
\hline \multicolumn{7}{|l|}{ Key Variable } \\
\hline $\begin{array}{l}\ln (\text { potential arable land per capita in the year } 1 \\
\text { AD) }\end{array}$ & 3.024 & 2.299 & $-0.0178^{* * *}$ & 0.0064 & $-0.0139^{* *}$ & 0.0066 \\
\hline \multicolumn{7}{|l|}{ Geo-Climatic Controls } \\
\hline $\ln ($ average yearly precipitation in $\mathrm{mm})$ & 6.661 & 0.881 & 0.0014 & 0.0195 & -0.0002 & 0.0218 \\
\hline monthly average temperature in degrees Celsius & 17.219 & 8.587 & $0.0071^{* *}$ & 0.0031 & 0.0050 & 0.0038 \\
\hline $\ln ($ mean elevation in $\mathrm{km})$ & -0.930 & 0.921 & 0.0289 & 0.0197 & $0.0420^{*}$ & 0.0221 \\
\hline $\ln$ (measure of terrain roughness) & -1.982 & 0.888 & $-0.0380^{*}$ & 0.0224 & $-0.0481^{* *}$ & 0.0239 \\
\hline fraction of land area in the geographical tropics & 0.426 & 0.481 & -0.0406 & 0.0463 & 0.0181 & 0.0579 \\
\hline $\begin{array}{l}\ln \text { (mean distance in } \mathrm{km} \text { to nearest coastline or } \\
\text { sea-navigable river) }\end{array}$ & 338.030 & 473.584 & 0.0000 & 0.0000 & 0.0000 & 0.0000 \\
\hline fraction of land area in which malaria is endemic & 0.617 & 0.409 & -0.0164 & 0.0292 & 0.0154 & 0.0318 \\
\hline \multicolumn{7}{|l|}{ Contemporary Controls } \\
\hline $\ln ($ nominal per capita income in 2012 - USD) & 8.502 & 1.496 & 0.0845 & 0.0690 & $0.1737^{*}$ & 0.0881 \\
\hline $\begin{array}{l}\ln (\text { nominal per capita income in } 2012 \text { - USD) } \\
\text { squared }\end{array}$ & 74.363 & 26.275 & $-0.0085^{* *}$ & 0.0040 & $-0.0140^{* * *}$ & 0.0051 \\
\hline dummy variable for Asia & 0.307 & 0.464 & 0.0730 & 0.0465 & 0.0718 & 0.0483 \\
\hline dummy variable for Europe & 0.297 & 0.459 & 0.0149 & 0.0563 & 0.0901 & 0.1290 \\
\hline dummy variable for N. America & 0.079 & 0.271 & $0.1774^{* * *}$ & 0.0579 & $0.1448^{*}$ & 0.0745 \\
\hline dummy variable for Oceania & 0.010 & 0.100 & $0.2605^{* * *}$ & 0.0936 & $0.1988^{* *}$ & 0.0989 \\
\hline dummy variable for S. America & 0.040 & 0.196 & $0.1442^{* *}$ & 0.0688 & 0.1212 & 0.0884 \\
\hline dummy variable for Sub-Saharan Africa & 0.228 & 0.421 & $0.1818^{* * *}$ & 0.0544 & $0.1295^{* *}$ & 0.0614 \\
\hline \multicolumn{7}{|l|}{ Additional Contemporary Controls } \\
\hline years of civil conflict $1816-2007$ & 8.762 & 16.386 & & & 0.0002 & 0.0006 \\
\hline years of inter-state conflict $1816-2007$ & 5.238 & 9.072 & & & 0.0000 & 0.0012 \\
\hline indicator of experience of communism & 0.307 & 0.464 & & & -0.0005 & 0.0307 \\
\hline fraction of population of European descent & 0.341 & 0.437 & & & -0.0758 & 0.1235 \\
\hline $\ln ($ agriculture's percentage share in GDP) & 2.004 & 1.201 & & & -0.0233 & 0.0211 \\
\hline $\ln ($ industry's percentage share in GDP) & 3.367 & 0.415 & & & -0.0413 & 0.0278 \\
\hline fraction of population that is Catholic & 0.266 & 0.332 & & & 0.0440 & 0.0481 \\
\hline fraction of population that is Protestant & 0.102 & 0.172 & & & $0.1207^{*}$ & 0.0705 \\
\hline $\begin{array}{l}\text { fraction of population belonging to other } \\
\text { Christian denominations }\end{array}$ & 0.076 & 0.116 & & & $0.1723^{*}$ & 0.0976 \\
\hline fraction of population that is Muslim & 0.271 & 0.366 & & & $0.1017^{* *}$ & 0.0450 \\
\hline fraction of population that is Hindu & 0.023 & 0.110 & & & 0.0974 & 0.0873 \\
\hline Adjusted $\mathrm{R}^{2}$ & & & \multicolumn{2}{|c|}{0.8570} & \multicolumn{2}{|c|}{0.8619} \\
\hline $\mathrm{n}$ & \multicolumn{6}{|c|}{$\begin{array}{l}101 \text { (sample excludes New World countries in which Europeans } \\
\text { make up half or more of the population) }\end{array}$} \\
\hline
\end{tabular}

Note: The superscripts ${ }^{* * *},{ }^{* *}$, and ${ }^{*}$ denote significance at the $1 \%, 5 \%$, and $10 \%$ levels, respectively. 
Table 3: Gender Inequality and Ancestral Arable Land

\begin{tabular}{|c|c|c|c|c|c|c|}
\hline & \multicolumn{2}{|c|}{ Sample Statistics } & \multicolumn{4}{|c|}{ OLS Estimates of Equation (3) } \\
\hline & Mean & S.E. & Coeff. & S.E. & Coeff. & S.E. \\
\hline Dependent Variable & & & \multicolumn{2}{|c|}{ baseline } & \multicolumn{2}{|c|}{ extended } \\
\hline Gender Inequality Index in 2012 & 0.384 & 0.186 & & & & \\
\hline \multicolumn{7}{|l|}{ Explanatory Variables } \\
\hline constant & & & $0.7288^{* * *}$ & 0.2731 & $0.5488^{*}$ & 0.3155 \\
\hline \multicolumn{7}{|l|}{ Key Variable } \\
\hline $\begin{array}{l}\ln \text { (percentage of country's ancestral lands } \\
\text { suited to agriculture) }\end{array}$ & 3.574 & 1.271 & $-0.0238^{* * *}$ & 0.0070 & $-0.0205^{* * *}$ & 0.0076 \\
\hline \multicolumn{7}{|l|}{ Ancestral Geo-Climatic Controls } \\
\hline $\begin{array}{l}\ln \text { (average monthly precipitation in ancestral } \\
\text { lands in } \mathrm{mm} \text { ) }\end{array}$ & 4.217 & 0.836 & -0.0133 & 0.0128 & 0.0053 & 0.0178 \\
\hline $\begin{array}{l}\text { daily average temperature in ancestral lands } \\
\text { in degrees Celsius }\end{array}$ & 17.935 & 6.911 & $0.0047^{*}$ & 0.0028 & 0.0044 & 0.0033 \\
\hline $\begin{array}{l}\text { In(percentage of ancestral lands with no } \\
\text { significant soil depth constraints) }\end{array}$ & -0.251 & 0.258 & $-0.0697^{*}$ & 0.0370 & -0.0671 & 0.0441 \\
\hline $\begin{array}{l}\text { In(terrain slope - rise as a percentage of run - } \\
\text { of ancestral lands) }\end{array}$ & 2.539 & 0.612 & $-0.0564^{* * *}$ & 0.0173 & $-0.0559^{* * *}$ & 0.0202 \\
\hline $\begin{array}{l}\text { fraction of ancestral lands in the tropical or } \\
\text { sub-tropical ecological zones }\end{array}$ & 0.734 & 0.423 & 0.0385 & 0.0419 & 0.0117 & 0.0449 \\
\hline $\begin{array}{l}\text { fraction of ancestral lands suited to crops } \\
\text { whose cultivation benefits greatly from } \\
\text { adoption of the plough }\end{array}$ & 0.519 & 0.404 & $0.1247^{* *}$ & 0.0486 & $0.1621^{* * *}$ & 0.0543 \\
\hline \multicolumn{7}{|l|}{ Contemporary Controls } \\
\hline $\ln ($ nominal per capita income in 2012 - USD) & 8.616 & 1.522 & 0.0694 & 0.0531 & 0.0869 & 0.0660 \\
\hline $\begin{array}{l}\ln (\text { nominal per capita income in } 2012 \text { - USD) } \\
\text { squared }\end{array}$ & 76.367 & 26.559 & $-0.0083^{* * *}$ & 0.0030 & $-0.0106^{* * *}$ & 0.0039 \\
\hline dummy variable for Asia & 0.281 & 0.451 & $0.0705^{*}$ & 0.0426 & 0.0733 & 0.0446 \\
\hline dummy variable for Europe & 0.230 & 0.422 & -0.0048 & 0.0487 & 0.0800 & 0.0703 \\
\hline dummy variable for N. America & 0.115 & 0.320 & $0.1599^{* * *}$ & 0.0506 & $0.1682^{* * *}$ & 0.0639 \\
\hline dummy variable for Oceania & 0.022 & 0.146 & 0.1035 & 0.0670 & $0.1821^{* *}$ & 0.0785 \\
\hline dummy variable for S. America & 0.086 & 0.282 & $0.1463^{* * *}$ & 0.0510 & $0.1807^{* * *}$ & 0.0627 \\
\hline dummy variable for Sub-Saharan Africa & 0.237 & 0.427 & $0.1961^{* * *}$ & 0.0496 & $0.1426^{* *}$ & 0.0576 \\
\hline \multicolumn{7}{|l|}{ Additional Contemporary Controls } \\
\hline years of civil conflict $1816-2007$ & 8.223 & 15.054 & & & 0.0002 & 0.0006 \\
\hline years of inter-state conflict $1816-2007$ & 4.971 & 8.671 & & & -0.0003 & 0.0012 \\
\hline indicator of experience of communism & 0.266 & 0.444 & & & -0.0120 & 0.0227 \\
\hline fraction of population of European descent & 0.342 & 0.423 & & & -0.0773 & 0.0534 \\
\hline $\ln ($ agriculture's percentage share in GDP) & 1.921 & 1.234 & & & $-0.0326^{*}$ & 0.0172 \\
\hline ln(industry's percentage share in GDP) & 3.336 & 0.421 & & & 0.0030 & 0.0211 \\
\hline fraction of population that is Catholic & 0.291 & 0.332 & & & -0.0007 & 0.0412 \\
\hline fraction of population that is Protestant & 0.119 & 0.183 & & & 0.0021 & 0.0583 \\
\hline $\begin{array}{l}\text { fraction of population belonging to other } \\
\text { Christian denominations }\end{array}$ & 0.091 & 0.122 & & & 0.0941 & 0.0816 \\
\hline fraction of population that is Muslim & 0.232 & 0.346 & & & $0.0888^{* *}$ & 0.0408 \\
\hline fraction of population that is Hindu & 0.026 & 0.106 & & & 0.1055 & 0.0732 \\
\hline
\end{tabular}


Table 3: Gender Inequality and Ancestral Arable Land (continued)

\begin{tabular}{|c|c|c|c|c|c|c|}
\hline & \multicolumn{2}{|c|}{ Sample Statistics } & \multicolumn{4}{|c|}{\begin{tabular}{|c|} 
OLS Estimates of Equation (3) \\
\end{tabular}} \\
\hline & Mean & S.E. & Coeff. & S.E. & Coeff. & S.E. \\
\hline Dependent Variable & & & \multicolumn{2}{|c|}{ baseline } & \multicolumn{2}{|c|}{ extended } \\
\hline \multicolumn{7}{|l|}{ Ancestral Historical Controls } \\
\hline $\begin{array}{l}\text { fraction of population with ancestors who } \\
\text { domesticated large animals }\end{array}$ & 0.927 & 0.203 & & & 0.0326 & 0.0612 \\
\hline $\begin{array}{l}\text { average number of levels of jurisdiction } \\
\text { (hierarchies) in ancestral societies }\end{array}$ & 3.320 & 1.059 & & & $-0.0221^{* *}$ & 0.0109 \\
\hline $\begin{array}{l}\text { index of the complexity of ancestral } \\
\text { settlement patterns }\end{array}$ & 6.285 & 1.360 & & & $0.0159^{*}$ & 0.0095 \\
\hline $\begin{array}{l}\text { fraction of population with ancestors who } \\
\text { practiced intensive agriculture }\end{array}$ & 0.605 & 0.432 & & & -0.0454 & 0.0341 \\
\hline $\begin{array}{l}\ln \text { (percentage share of the herding of large } \\
\text { animals in ancestral subsistence activities) }\end{array}$ & 3.055 & 0.683 & & & 0.0329 & 0.0252 \\
\hline $\begin{array}{l}\ln \text { (percentage share of hunting in ancestral } \\
\text { subsistence activities) }\end{array}$ & 1.545 & 0.700 & & & 0.0216 & 0.0212 \\
\hline $\begin{array}{l}\text { fraction of population with ancestors in } \\
\text { whose societies there was an absence of } \\
\text { inheritance rights to land }\end{array}$ & 0.132 & 0.280 & & & 0.0171 & 0.0352 \\
\hline $\begin{array}{l}\text { fraction of population with ancestors whose } \\
\text { societies were patrilocal }\end{array}$ & 0.659 & 0.416 & & & -0.0323 & 0.0264 \\
\hline $\begin{array}{l}\text { fraction of population with ancestors whose } \\
\text { societies were matrilocal }\end{array}$ & 0.040 & 0.136 & & & -0.0616 & 0.0711 \\
\hline $\begin{array}{l}\text { fraction of population with ancestors who } \\
\text { lived in nuclear families }\end{array}$ & 0.317 & 0.376 & & & -0.0088 & 0.0485 \\
\hline $\begin{array}{l}\text { fraction of population with ancestors who } \\
\text { lived in extended families }\end{array}$ & 0.556 & 0.396 & & & -0.0553 & 0.0460 \\
\hline $\begin{array}{l}\text { average year of first observation of country's } \\
\text { constituent ethnic groups }\end{array}$ & 1744.525 & 715.999 & & & 0.00002 & 0.00002 \\
\hline Adjusted $\mathrm{R}^{2}$ & & & \multicolumn{2}{|c|}{0.8282} & \multicolumn{2}{|c|}{0.8499} \\
\hline $\mathrm{n}$ & \multicolumn{6}{|c|}{139} \\
\hline
\end{tabular}

Note: The superscripts ${ }^{* * *},{ }^{* *}$, and ${ }^{*}$ denote significance at the $1 \%, 5 \%$, and $10 \%$ levels, respectively. 
Table 4: Gender Inequality and Potential arable land: An Illustrative Summary

\begin{tabular}{|c|c|c|c|c|}
\hline & & & $\begin{array}{l}\text { Value of the Gender } \\
\text { Inequality Index in } 2012\end{array}$ & $\begin{array}{l}\text { Percentage of Land Area } \\
\text { that is Potentially Arable }\end{array}$ \\
\hline \multirow{2}{*}{$\begin{array}{l}1^{\text {st }} \text { decile of per capita } \\
\text { income in } 2012\end{array}$} & $\begin{array}{l}\text { Country with least } \\
\text { gender inequality }\end{array}$ & Rwanda & 0.414 & 30.24 \\
\hline & $\begin{array}{l}\text { Country with most } \\
\text { gender inequality }\end{array}$ & Niger & 0.707 & 8.11 \\
\hline \multirow{2}{*}{$\begin{array}{l}2^{\text {nd }} \text { decile of per capita } \\
\text { income }\end{array}$} & $\begin{array}{l}\text { Country with least } \\
\text { gender inequality }\end{array}$ & Tajikistan & 0.338 & 13.55 \\
\hline & $\begin{array}{l}\text { Country with most } \\
\text { gender inequality }\end{array}$ & Afghanistan & 0.712 & 4.66 \\
\hline \multirow{2}{*}{$\begin{array}{l}3^{\text {rd }} \text { decile of per capita } \\
\text { income }\end{array}$} & $\begin{array}{l}\text { Country with least } \\
\text { gender inequality }\end{array}$ & Vietnam & 0.299 & 37.39 \\
\hline & $\begin{array}{l}\text { Country with most } \\
\text { gender inequality }\end{array}$ & Yemen & 0.747 & 0.01 \\
\hline \multirow{2}{*}{$\begin{array}{l}4^{\text {th }} \text { decile of per capita } \\
\text { income }\end{array}$} & $\begin{array}{l}\text { Country with least } \\
\text { gender inequality }\end{array}$ & Mongolia & 0.328 & 0.11 \\
\hline & $\begin{array}{l}\text { Country with most } \\
\text { gender inequality }\end{array}$ & Rep. Congo & 0.610 & 67.34 \\
\hline \multirow{2}{*}{$\begin{array}{l}5^{\text {th }} \text { decile of per capita } \\
\text { income }\end{array}$} & $\begin{array}{l}\text { Country with least } \\
\text { gender inequality }\end{array}$ & Macedonia & 0.162 & 39.93 \\
\hline & $\begin{array}{l}\text { Country with most } \\
\text { gender inequality }\end{array}$ & Jordan & 0.482 & 6.34 \\
\hline \multirow{2}{*}{$\begin{array}{l}6^{\text {th }} \text { decile of per capita } \\
\text { income }\end{array}$} & $\begin{array}{l}\text { Country with least } \\
\text { gender inequality }\end{array}$ & China & 0.213 & 21.62 \\
\hline & $\begin{array}{l}\text { Country with most } \\
\text { gender inequality }\end{array}$ & Iraq & 0.557 & 10.14 \\
\hline \multirow{2}{*}{$\begin{array}{l}7^{\text {th }} \text { decile of per capita } \\
\text { income }\end{array}$} & $\begin{array}{l}\text { Country with least } \\
\text { gender inequality }\end{array}$ & Poland & 0.140 & 91.99 \\
\hline & $\begin{array}{l}\text { Country with most } \\
\text { gender inequality }\end{array}$ & Panama & 0.503 & 31.79 \\
\hline \multirow{2}{*}{$\begin{array}{l}8^{\text {th }} \text { decile of per capita } \\
\text { income }\end{array}$} & $\begin{array}{l}\text { Country with least } \\
\text { gender inequality }\end{array}$ & Slovenia & 0.080 & 50.15 \\
\hline & $\begin{array}{l}\text { Country with most } \\
\text { gender inequality }\end{array}$ & Uruguay & 0.367 & 81.39 \\
\hline \multirow{2}{*}{$\begin{array}{l}9^{\text {th }} \text { decile of per capita } \\
\text { income }\end{array}$} & $\begin{array}{l}\text { Country with least } \\
\text { gender inequality }\end{array}$ & Germany & 0.075 & 80.69 \\
\hline & $\begin{array}{l}\text { Country with most } \\
\text { gender inequality }\end{array}$ & Saudi Arabia & 0.682 & 0.00 \\
\hline \multirow{2}{*}{$\begin{array}{l}10^{\text {th }} \text { decile of per capita } \\
\text { income }\end{array}$} & $\begin{array}{l}\text { Country with least } \\
\text { gender inequality }\end{array}$ & Netherlands & 0.045 & 55.03 \\
\hline & $\begin{array}{l}\text { Country with most } \\
\text { gender inequality }\end{array}$ & Qatar & 0.546 & 0.09 \\
\hline
\end{tabular}


Table 5: Determinants of Ancestral Plough Use

\begin{tabular}{|c|c|c|c|c|}
\hline & \multicolumn{2}{|c|}{ Sample Statistics } & \multicolumn{2}{|c|}{ OLS Estimates } \\
\hline & Mean & S.E. & Coeff. & S.E. \\
\hline \multicolumn{5}{|l|}{ Dependent Variable } \\
\hline fraction of population with ancestors who used the plough & 0.518 & 0.477 & & \\
\hline \multicolumn{5}{|l|}{ Explanatory Variables } \\
\hline Constant & & & 0.1663 & 0.4713 \\
\hline \multicolumn{5}{|l|}{ Key Variable } \\
\hline $\begin{array}{l}\ln \text { (percentage of country's ancestral lands } \\
\text { suited to agriculture) }\end{array}$ & 3.676 & 1.192 & $-0.0476^{* * *}$ & 0.0164 \\
\hline \multicolumn{5}{|l|}{ Ancestral Geo-Climatic Controls } \\
\hline $\begin{array}{l}\text { fraction of ancestral lands suited to crops whose cultivation benefits } \\
\text { greatly from adoption of the plough }\end{array}$ & 0.483 & 0.413 & $0.4171^{* * *}$ & 0.1017 \\
\hline $\ln ($ average monthly precipitation in ancestral lands in $\mathrm{mm}$ ) & 4.238 & 0.807 & -0.0300 & 0.0395 \\
\hline daily average temperature in ancestral lands in degrees Celsius & 18.669 & 6.946 & 0.0015 & 0.0065 \\
\hline $\ln$ (percentage of ancestral lands with no significant soil depth constraints) & 4.363 & 0.248 & -0.0645 & 0.0832 \\
\hline $\ln$ (terrain slope - rise as a percentage of run - of ancestral lands) & 2.485 & 0.643 & -0.0235 & 0.0402 \\
\hline fraction of ancestral lands in the tropical or sub-tropical ecological zones & 0.744 & 0.417 & -0.1123 & 0.0835 \\
\hline \multicolumn{5}{|l|}{\begin{tabular}{|l|l} 
Continent Dummy Variables &
\end{tabular}} \\
\hline dummy variable for Asia & 0.235 & 0.425 & 0.0765 & 0.0864 \\
\hline dummy variable for Europe & 0.205 & 0.405 & -0.0379 & 0.0987 \\
\hline dummy variable for N. America & 0.175 & 0.381 & -0.1996 & 0.1001 \\
\hline dummy variable for Oceania & 0.040 & 0.196 & -0.1630 & 0.1265 \\
\hline dummy variable for S. America & 0.070 & 0.256 & $-0.2094^{*}$ & 0.1120 \\
\hline dummy variable for Sub-Saharan Africa & 0.235 & 0.425 & -0.1505 & 0.0980 \\
\hline \multicolumn{5}{|l|}{ Ancestral Historical Controls } \\
\hline fraction of population with ancestors who domesticated large animals & 0.943 & 0.185 & -0.0675 & 0.1345 \\
\hline average number of levels of jurisdiction (hierarchies) in ancestral societies & 3.415 & 1.000 & $0.0900^{* * *}$ & 0.0225 \\
\hline index of the complexity of ancestral settlement patterns & 6.343 & 1.427 & 0.0304 & 0.0190 \\
\hline fraction of population with ancestors who practiced intensive agriculture & 0.557 & 0.449 & $0.2110^{* * *}$ & 0.0657 \\
\hline $\begin{array}{l}\ln \text { (percentage share of the herding of large animals in ancestral } \\
\text { subsistence activities) }\end{array}$ & 3.043 & 0.681 & 0.0611 & 0.0498 \\
\hline $\ln$ (percentage share of hunting in ancestral subsistence activities) & 1.418 & 0.663 & 0.0551 & 0.0388 \\
\hline $\begin{array}{l}\text { fraction of population with ancestors in whose societies there was an } \\
\text { absence of inheritance rights to land }\end{array}$ & 0.106 & 0.252 & $-0.2226^{* * *}$ & 0.0761 \\
\hline fraction of population with ancestors whose societies were patrilocal & 0.677 & 0.418 & -0.0670 & 0.0594 \\
\hline fraction of population with ancestors whose societies were matrilocal & 0.033 & 0.124 & 0.0552 & 0.1582 \\
\hline fraction of population with ancestors who lived in nuclear families & 0.304 & 0.384 & $0.1573^{*}$ & 0.0907 \\
\hline fraction of population with ancestors who lived in extended families & 0.583 & 0.406 & 0.0536 & 0.0815 \\
\hline average year of first observation of country's constituent ethnic groups & 1774.432 & 620.647 & 0.0001 & 0.00003 \\
\hline Adjusted $\mathrm{R}^{2}$ & & & & 320 \\
\hline $\mathrm{n}$ & & & 00 & \\
\hline
\end{tabular}

Note: The superscripts ${ }^{* * *},{ }^{* *}$, and ${ }^{*}$ denote significance at the $1 \%, 5 \%$, and $10 \%$ levels, respectively. 
Figure 1: World Choropleth Map of Gender Inequality Per the UNDP's Gender Inequality Index for 2012

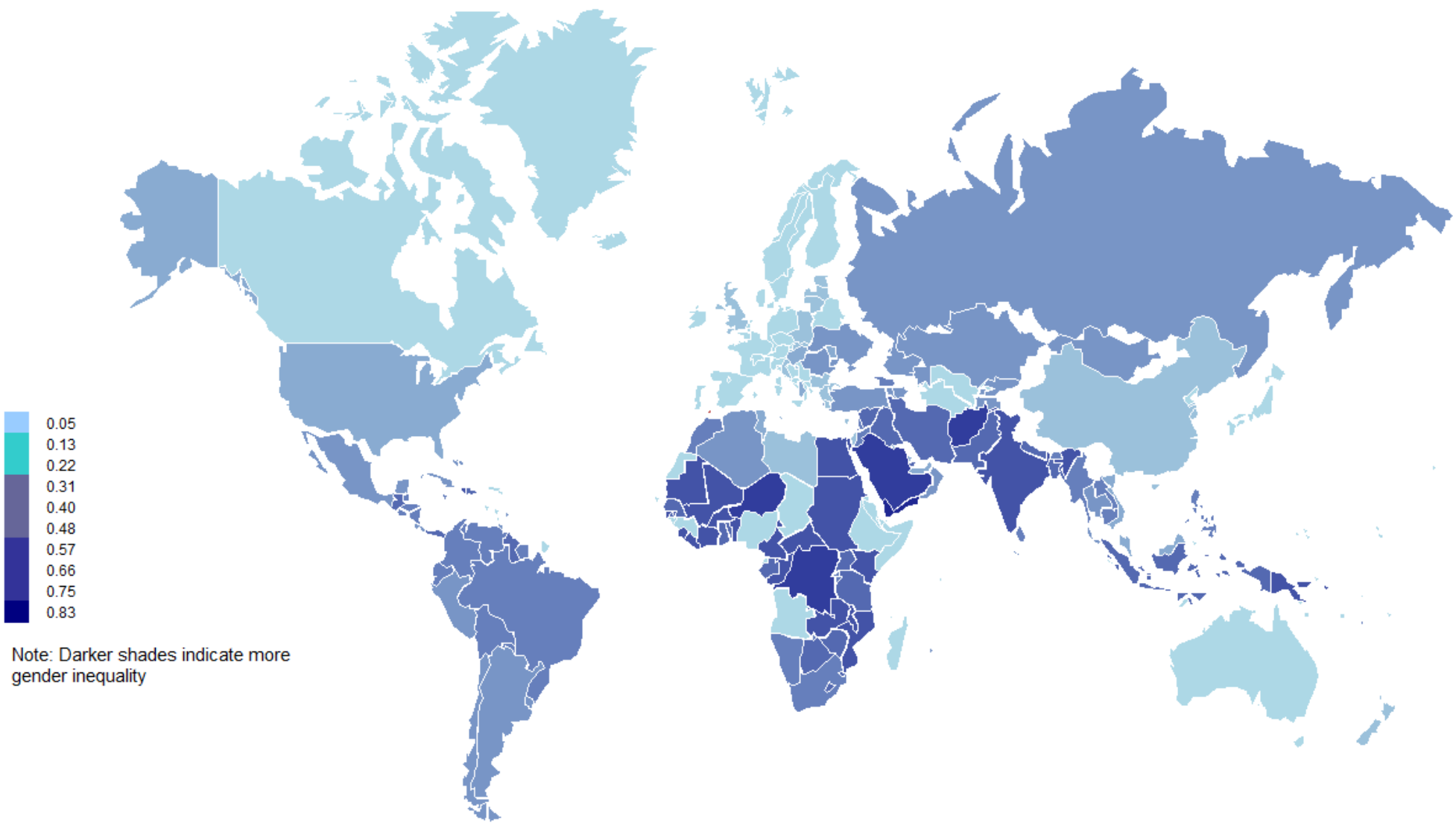


Figure 2: Scatter Plot of Per Capita Income Against the Gender Inequality Index

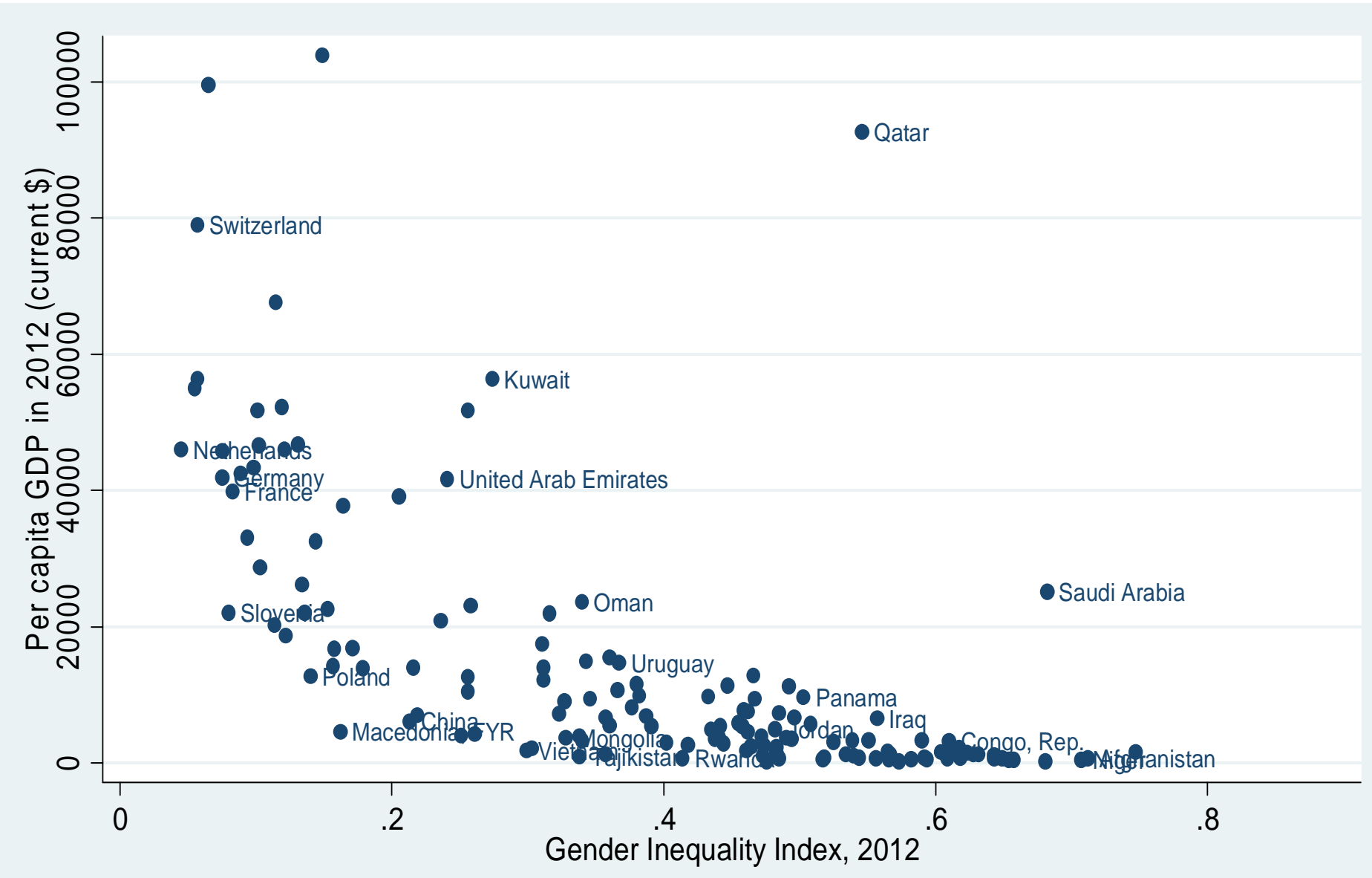


Figure 3: Three-Dimensional Scatter Plot of the Gender Inequality Index Against Both the Proportion of National Land Area that is Potentially Arable and Per Capita Income

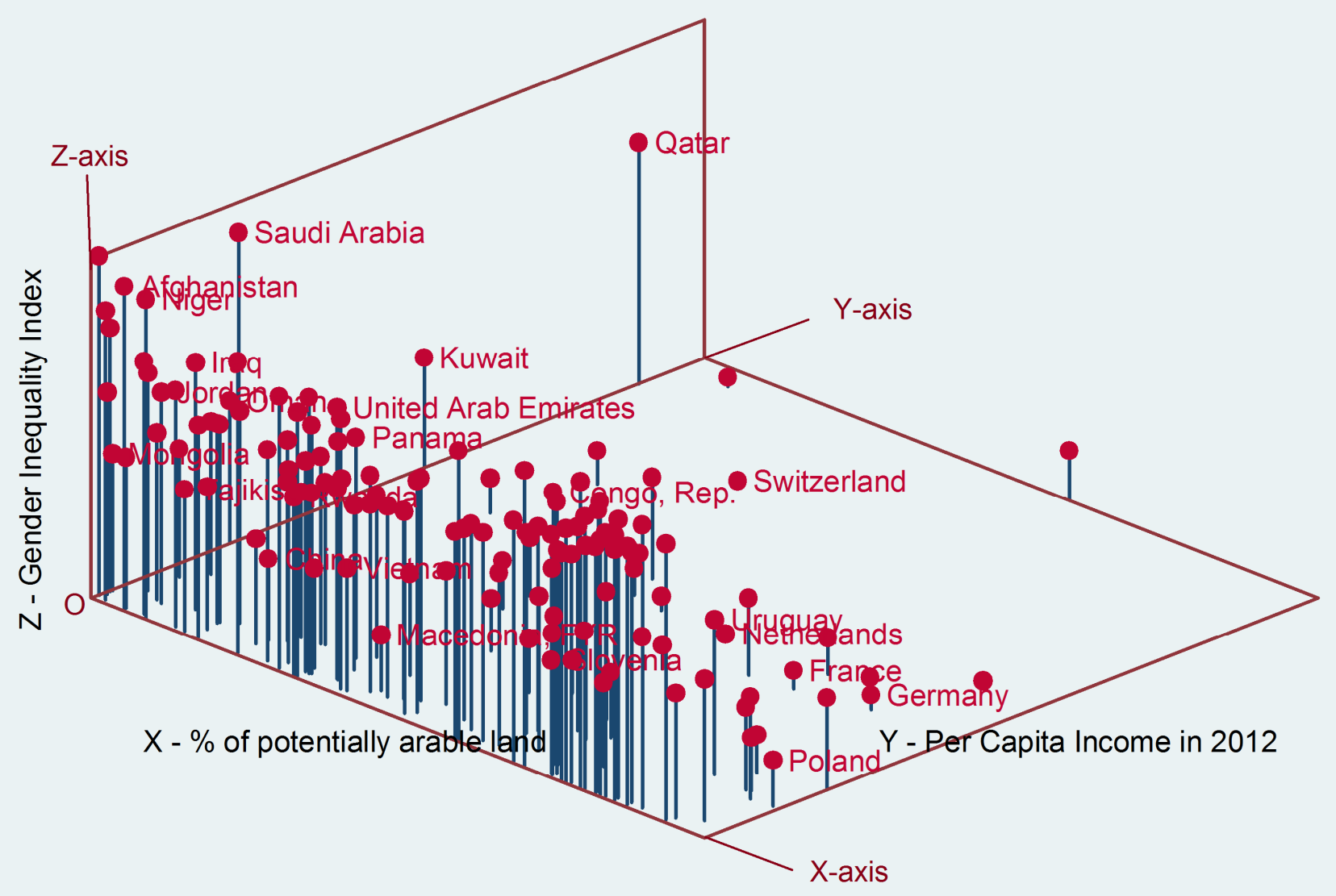


Figure 4: Three-Dimensional Scatter Plot of the Proportion of National Land Area that is Potentially Arable Against Both the Gender Inequality Index and Per Capita Income

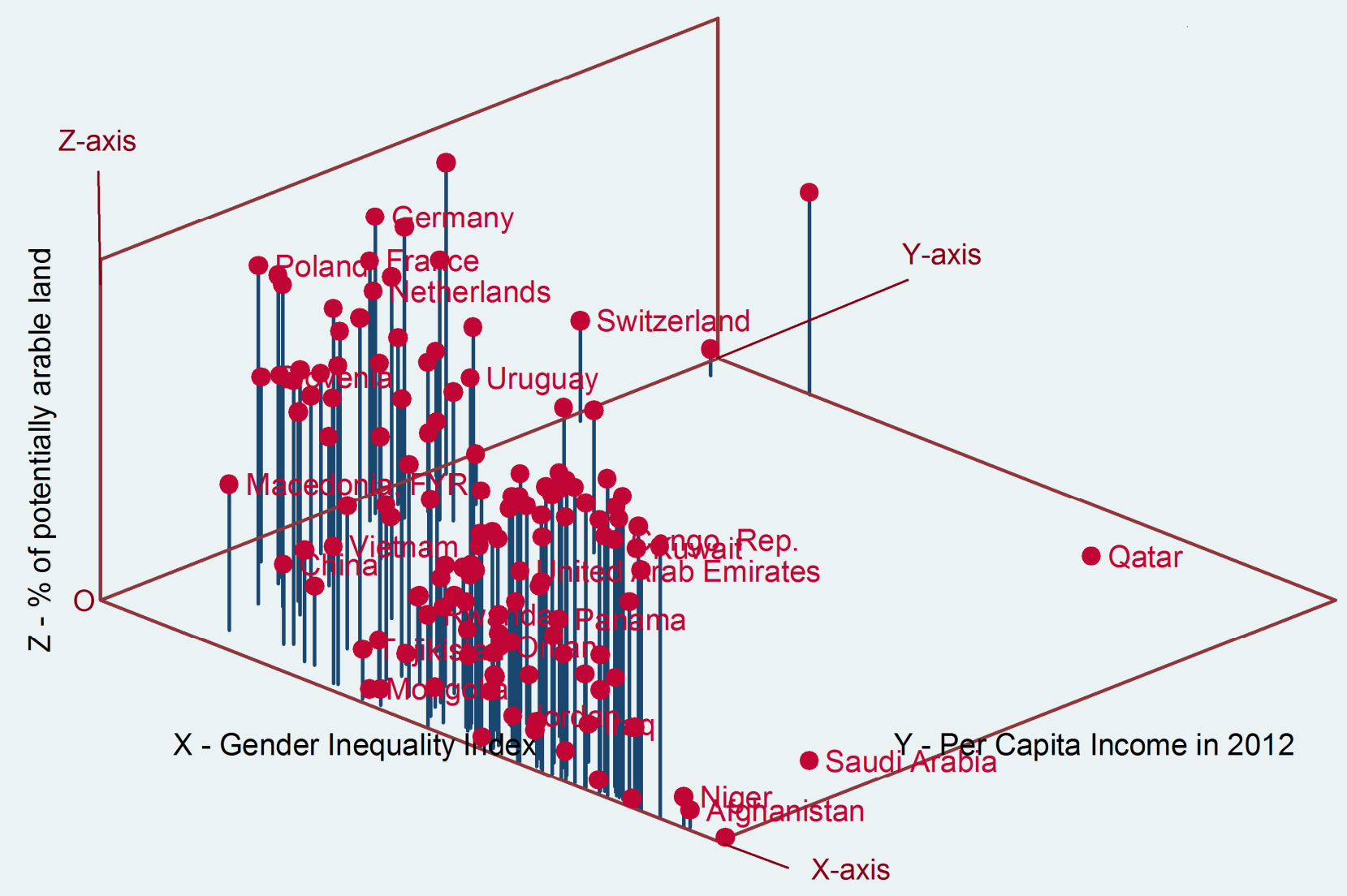




\section{References}

Alderman, H., Gertler, P., 1997. Family Resources and Gender Differences in Human Capital Investments: the Demand for Children's Medical Care in Pakistan. In: Haddad, L., Hoddinott, J., Alderman, H. (Eds.), Intrahousehold Resource Allocation in Developing Countries: Methods, Models, and Policy. Johns Hopkins University Press, Baltimore.

Alesina, A., Giuliano, P., and Nunn, N., 2013. On the Origins of Gender Roles: Women and the Plough. The Quarterly Journal of Economics, 128(2), pp. 469-530.

Ashraf, Q., and Galor, O., 2013. The ‘Out of Africa’ Hypothesis, Human Genetic Diversity, and Comparative Economic Development. American Economic Review, 103(1), pp. 1-46.

Boserup, E., 1965. The Conditions of Agricultural Growth. Chicago: Aldine.

Brackman, H., 2008. Hatred in Hard Times - And How to Combat It: Lessons from History for the $21^{\text {st }}$ Century. Mimeo, Simon Wiesenthal Center, Los Angeles.

Bradshaw, P. F., 2002. The Search for the Origins of Christian Worship: Sources and Methods for the Study of Early Liturgy. New York: Oxford University Press.

Diamond, J., 1987. The Worst Mistake in the History of the Human Race. Discover magazine, May 1987.

Duleep,H. O., 2012. The Labor/Land Ratio and India's Caste System. Discussion Paper No. 6612. Institute for the Study of Labor, Bonn.

FAO, 2000. Land Resource Potential and Constraints at Regional and Country Levels. World Soils Report 90, Land and Water Division, Food and Agricultural Organization of the United Nations, Rome.

Gallup, J. L., Sachs, J. D., and Mellinger, A. D., 1999. Geography and Economic Development. International Regional Science Review, 22(2), pp. 179-232.

Hazarika, G., 2000. Gender Differences in Children's Nutrition and Access to Health Care in Pakistan. The Journal of Development Studies, 37(1), pp. 73-92.

Jones, P. D. and Mann, M. E., 2004. Climate Over Past Millennia. Review of Geophysics, 42(2), pp. 1-42.

Krosch, A. R. and Amodio, D. M., 2014. Economic Scarcity Alters the Perception of Race. Proceedings of the National Academy of Sciences, 111(25), pp. 9079-9084. 
Kuran, T., 2011. The Long Divergence: How Islamic Law Held Back the Middle East. Princeton: Princeton University Press.

McLennan, M. C., 2003. Labor Market Conditions and the Economic Status of Black Men: A Note. Industrial Relations, 42(1), pp. 78-86.

McEvedy, C. and Jones, R. 1978. Atlas of World Population History. New York, NY: Penguin Books Ltd.

Nunn, N. and Puga, D., 2012. Ruggedness: The Blessing of Bad Geography in Africa. Review of Economics and Statistics, 94(1), pp. 20-36.

Nunn, N. and Wantchekon, L., 2011. The Slave Trade and the Origins of Mistrust in Africa. American Economic Review, 101(7), pp. 3221-3252.

Sachs, J. and Malaney, P., 2002. The Economic and Social Burden of Malaria. Nature, 415(6872), pp. 680-685.

Schmitz, S. and Gabriel, P.E., 1992. The Impact of Changes in Local Labor Market Conditions on Estimates of Occupational Segregation. Review of Black Political Economy, 21(1), pp. 45-58.

Spolaore, E. and Wacziarg, R., 2009. The Diffusion of Development. The Quarterly Journal of Economics, 124(2), pp. 469-529.

Weber, M., 1930. The Protestant Ethic and the Spirit of Capitalism. New York: Scribner. 